\title{
A unidade entre Cristo e a Igreja: funcões teológicas para prática do cuidado com o próximo
}

\section{Unity between Christ and the Church: Theological functions for caring for others}

\author{
André Luiz Rodrigues da Silva* \\ Leonardo Henrique Piacente** \\ Marcelo Massao Osava***
}

Recebido em: 01/11/2019. Aceito em: 22/11/2019.

Resumo: Neste artigo nos unimos para propor uma interpretação do texto do evangelho de Lucas sobre o bom samaritano numa perspectiva de complementariedade entre Cristologia e Eclesiologia, observando o tema do cuidado com o próximo proposto pela Conferência Nacional dos Bispos do Brasil para a Campanha da Fraternidade de 2020. A parábola sugeriu a grandes autores interpretações diversas sobre o significado do samaritano e da hospedaria. No entanto, não faltaram momentos em que estas interpretações se tornaram unilaterais ao ponto de condicionar erros pastorais significativos. A partir do pensamento agostiniano, vemos a possibilidade de observar a parábola de maneira mais ampla e aproveitamos para aplicar o conceito ao plano quaresmal proposto no texto-base da Campanha da Fraternidade de 2020.

* Doutor em Ciência e Teologia Patrística (Institutum Patristicum Augustinianum, Roma, 2012). Mestre em Ciência e Teologia Patrística (Institutum Patristicum Augustinianum, Roma, 2008). Graduado em Teologia (Pontifícia Universidade Católica do Rio de Janeiro, 2002). Graduado em Filosofia (Faculdade Eclesiástica de Filosofia João Paulo II, Rio de Janeiro, 1998).

E-mail: leleur@yahoo.it

** Doutorando em Teologia (Pontifícia Universidade Católica do Rio de Janeiro, PUC-Rio). Mestre em Ciências da Religião (Pontifícia Universidade Católica de Campinas, 2016). Graduado em Teologia (Pontifícia Universidade Católica de Campinas, 2007). Graduado em Filosofia (Universidade Estadual de Campinas, UNICAMP, 2003). E-mail: lepiacente@yahoo.com.br

*** Mestrando em Teologia (Pontifícia Universidade Católica do Rio de Janeiro). Graduado em Sistemas de Informação (Associação Fluminense de Educação, UNIGRANRIO, Rio de Janeiro, 2007). Graduação em Teologia (Claretiano Centro Universitário, 2017). E-mail: marcelorb@gmail.com 
Palavras-Chave: Cristologia. Eclesiologia. CF 2020.

Abstract: In this paper we make an issue of new interpretation on the text of Luke's Gospel about the good Samaritan, aiming to offer a new significance over Christology and Ecclesiology based on a complementary process in Theology. The National Conference of Bishops of Brazil proposed entitling the Campanha da Fraternidade 2020 (National Charity Program) as "Taking care of our neighbors". That topic stimulated us to major in the past interpretations that great authors gave in order to explain the meaning of the Samaritan and the House of the parable. However, we could observe that those good explanations may improve condition for mistakes with pastoral effects. According to Saint Augustine, there is a hermeneutic rule that associates Christ and the Church in a very wide way which we assume in order to read the Lent Program available in the Texto-Base of the National Charity Program for 2020.

Keywords: Christology. Ecclesiology. CF 2020.

\section{Eclesiocentrismo pastoral e a experiência de fé}

A parábola do bom samaritano, que ilustra de modo tão atual e pertinente a proposta apresentada pela Conferência Nacional do Bispos do Brasil para a Campanha da Fraternidade de 2020, adquiriu o status de um dos textos mais tradicionais sobre a caridade devida aos necessitados.

Talvez pareça bastante simples ou precipitado identificar apenas o personagem caído, ferido e assaltado, para tentar responder à pergunta que o doutor da lei tinha elaborado em tom de intimidação, questionando Jesus sobre quem deveria ser o próximo ${ }^{1}$. No entanto, as coisas se tornam bem mais complexas quando, ao refazer a pergunta, Jesus a elabora de tal maneira que o homem caído se torna a referência para que se descubra o que devemos fazer pelo próximo ${ }^{2}$. Em última análise, a parábola não se compromete em responder quem é o próximo, por quanto óbvio isso possa parecer, mas se ajusta ao significado mais profundo de como devemos amar o próximo ${ }^{3}$. Não há dúvida, então, que a resposta que Jesus queria ouvir foi dada pelo doutor da lei, enquanto esse reconhece que o samaritano, dentre as três possibilidades de resposta, tinha sido o único a se apresentar na condição de próximo, ao usar de misericórdia ${ }^{4}$.

1 BíBLIA de Jerusalém. 5. ed. São Paulo: Paulus, 2008; Lc 10,29.

2 LC 10,36

3 LEVINE, Amy J.; WINTERINGTON, Ben. The Gospel of Luke. Cambridge: Cambridge University Press, 2018. p. 294.

4 LC $10,37$. 
Seguindo as indicações de Orígenes ${ }^{5}$, qualquer um que queira interpretar os elementos dessa parábola com finalidade eclesiológica poderá começar afirmando que o bom samaritano representa Cristo, enquanto a hospedaria é uma alegoria da Igreja. Tais designações da hermenêutica do texto de Lucas foram transmitidas de modo que, com frequência, podem ser ouvidas e reproduzidas como a maneira mais tradicional de se interpretar os elementos deste evangelho. Corrobora para isso o fato do papa Bento XVI também se apoiar neste tipo de leitura, manifestando que Cristo, da mesma forma que o bom samaritano, veio para sarar as feridas da humanidade que encontrou decaída, conduzindo-a à estalagem onde essa encontra segurança e restaura a sua saúde, ou seja, sob os cuidados da própria Igreja ${ }^{6}$.

De certo modo, esse tipo de interpretação não se torna totalmente imune aos excessos daqueles que, por vezes valendo-se da autoridade de exímios mestres, definem as suas conclusões de maneira demasiadamente equivocada. Vale dizer que, quando, no plano da evangelização, diz-se que obra de Cristo é conduzir o homem para a Igreja, da mesma forma que o bom samaritano conduziu o ferido para a hospedaria, não faltam os que colocam bastante relevo na dimensão institucional da promoção pastoral. Segundo Mário F. Miranda, segue-se a direção de uma teologia da conclusão, cujas consequências são, entre outras coisas, o patrocínio do clericalismo como fruto de um intelectualismo da fé acompanhado de uma apologética pretensiosamente racional, onde se destacam a passividade dos leigos e a ausência da experiência de fé 7 .

Mencionamos alguns defeitos, na brevidade de tal estudo, decorrentes de uma eclesiocentrismo pastoral que acaba condicionando a experiência que se faz da fé:

Em primeiro lugar, consideramos, com o discernimento do próprio papa Bento XVI, que a proposta do Concílio Vaticano II em reavaliar a importância do ministério sacerdotal ainda encontra resistência, ou por causa de uma concepção utilitarista do sacerdócio, como se a essência do ministério ordenado fosse reduzida ao seu aspecto sociofuncional, ou

5 ORIGEN. Homilies on Luke: Fragments on Luke. Trad. Joseph T. Lienhard. New York: The Catholic University of America Press, 1996. p. 138.

6 BENTO XVI. Jesus de Nazaré: Do batismo no Jordão à Transfiguração. Trad. José J. F. de Farias. São Paulo: Editora Planeta do Brasil, 2007. p. 178-179.

7 MIRANDA, Mário de F. Inculturação da fé: uma abordagem teológica. São Paulo: Edições Loyola, 2001. p. 76. 
por causa da estrutura ontológico-sacramental pela qual o sacerdote é entendido como o agente exclusivo do serviço, destinado a realização desta única tarefa ${ }^{8}$. Neste sentido, muito do eclesiocentrismo que conhecemos depende da concepção que construímos sobre o sacerdócio ministerial.

Em segundo lugar, estão as iniciativas missionárias e evangelizadoras que geram certo proselitismo paroquial que se repete como projeto de ação pastoral destinado à manutenção dos templos sagrados, ao preenchimento dos espaços vazios e à atenção exaustiva dos próprios membros, conservando um estilo "ad intra" menos condizente com o espírito conciliar missionário9. Intensifica-se a gravidade destas iniciativas diante do perfil competitivo entre as paróquias, sobretudo naqueles centros pastorais onde o sentimento de pertença à Igreja cede aos modelos de adesão religiosa construídos sobre projetos particulares de determinados párocos ou líderes cristãos, em detrimento dos valores eclesiológicos mais profundos e verdadeiros. Com isso, ouve-se com mais rigor a proposta do Documento de Aparecida, pela qual os bispos propunham uma conversão pastoral missionária para além da mera conservação ${ }^{10}$.

Em terceiro lugar, especialmente no que diz respeito ao Brasil, observamos um índice ascendente de voluntariado não qualificado e mal-intencionado. Cria-se, por assim dizer, um contexto onde grande parte dos esforços se concentra em tarefas e instruções desmotivadoras, quando não, inapropriadas.

Em quarto lugar, seguindo a problemática do item anterior, o incentivo econômico no que diz respeito aos projetos de reforma da igreja, de acúmulo de bens e da manutenção do culto se apresenta muito mais razoável e concreto do que os recursos que servem para os projetos de ordem missionária, destinados às pessoas que não frequentem ou que, em última análise, não formem aquele núcleo imediato da paróquia.

Em último lugar, englobamos todos os possíveis exemplos de um sistema que, apesar de obsoleto, prefere promover o paradigma

8 RATZINGER, Joseph. Convocados en el camino de la fe: La iglesia como comunión. Trad. José R. M. Fernandez. Madrid: Cristiandad, 2004. p. 160.

9 SUESS, Paulo. Perspectivas pastorais em vista do terceiro milênio. Revista de Cultura Teológica, São Paulo, n. 17, p. 9-27, out/dez 1996. p. 25.

10 CONFERÊNCIA GERAL DO EPISCOPADO LATINO-AMERICANO E DO CARIBE, V, 2007, Aparecida. Documento de Aparecida: texto conclusivo. 7. ed. Brasília: CNBB, 2008. p. 169; DAp. 370. 
eclesiocentrista institucional a se adaptar aos modelos mais originais e autênticos da fé cristã.

Se houvéssemos de indicar com uma analogia um dos personagens da parábola para descrever o modelo teológico inerente aos defeitos relacionados acima, certamente escolheríamos, no sacerdote e no levita que não pararam para ajudar aquele homem, os mesmos traços de uma religião centralizadora e egoísta. Em suma, o papa Francisco ressalta que, dentre as tentações pastorais que devemos superar, precisamos prestar atenção no fato de pertencer ainda à Igreja excessivo clericalismo ${ }^{11}$.

\section{Cristocentrismo pastoral e a relativização da religião}

Quase como uma reação aos problemas institucionais, surge outra proposta hermenêutica, tentando inverter o significado dos elementos da parábola. Desta vez, opta-se por ver no samaritano a figura da Igreja e na hospedaria, Cristo.

Seguindo tal hermenêutica, o Documento de Aparecida ressaltou que o processo de evangelização deve progredir sempre a partir da promoção humana e de uma autêntica libertação cristã, apresentando ao mundo o rosto de uma Igreja samaritana ${ }^{12}$. Para Ezequiel M. Silva, o Celam está seguindo os passos apresentados por Jon Sobrino ao constituir a primeira vez que o magistério episcopal latino-americano utiliza esta categoria eclesiológica ${ }^{13}$.

Em termos de solidariedade, humaniza-se mais os princípios da evangelização e se introduz com mais rapidez os leigos no reconhecimento da vulnerabilidade do seu semelhante, segundo a dinâmica de partilha associada ao dom de Deus que se ordena para a justiça e cria condições favoráveis para o desenvolvimento do próximo ${ }^{14}$.

11 FRANCISCO. Exortação Apostólica Evangelii Gaudium. Brasília: Edições CNBB, 2013. p. 63; EG 102.

12 CONFERÊNCIA GERAL DO EPISCOPADO LATINO-AMERICANO E DO CARIBE, V, 2008. p. 23; DAp. 26.

13 SILVA, Ezequiel M. Una teología samaritana: el estilo teológico de Jon Sobrino. Revista Teología, Buenos Aires, T. XLVII, n. 104, p. 81-109, abril 2011. p. 108.

14 MENESES, Ramiro D. B. O vulnerável segundo a parábola do Bom Samaritano. Revista Cultura Teológica, São Paulo, v. 14, n. 56, p. 9-35, jul/set 2006. p. 34. 
No entanto, se no primeiro caso a tendência de se depositar demasiado acento na dimensão eclesiológico-institucional colocava em risco elementos importantes para a evangelização, dessa vez o perigo se apresenta ao condicionar a experiência missionária à relativização da religião em nome de um cristocentrismo pastoral que se revela na subjetividade de fé que cada pessoa constrói.

Outra vez, deve-se mostrar os defeitos que esse tipo de abordagem pode trazer para a perspectiva da evangelização.

Antes de tudo, voltamos ao Documento de Aparecida, onde a questão da subjetividade da fé é um alerta para a perda de uma concepção integral do ser humano que, ao mesmo tempo que exclui o verdadeiro Deus do seu horizonte, vai em busca de razões que respaldem os seus equívocos e a sua mentalidade destrutiva ${ }^{15}$. Pelo que parece, o fato de se transferir as responsabilidades sobre o protagonismo pastoral não resolve tanto a questão, uma vez que isso alimente algum tipo de desvio de entendimento sobre a perspectiva teológica e espiritual.

Ademais, o contexto protestante e evangélico promove um discurso de adesão rápida da parte dos seus membros, propondo - como explica Alencar Silveira Filho - um trânsito religioso nutrido pela ressignificação que o sujeito dá para as suas crenças ao mesmo tempo que produz um ambiente polivalente, menos institucionalizado, que se adapta "às novas crenças resinificadas pelas pessoas" ${ }^{16}$. Também em contexto católico, avalia-se brevemente o impacto desse modo de pensar. De fato, uma maior sensibilidade para o apelo do mandamento pelo qual se deve amar o próximo pode corresponder a uma diminuição da importância que se dá aos aspectos contemplativos da espiritualidade cristã, revelando que o mesmo lugar onde cresce o risco da secularização se estabelece o subjetivismo cristão ${ }^{17}$.

Outrossim, não precisamos analisar com tanto rigor os manuais de vida cristã, para constatar que o conhecimento básico sobre o ensinamento e a obra de Jesus Cristo se diluiu em conceitos que acabam por refazer o

15 CONFERÊNCIA GERAL DO EPISCOPADO LATINO-AMERICANO E DO CARIBE, V, 2008. p. 32; DAp. 44.

16 SILVEIRA FILHO, Alencar. O processo de diversificação denominacional do protestantismo brasileiro. Revista Unitas, Vitória, v. 5, n. 1, p. 187-202, 2017. p. 194.

17 AUMANN, Jordan. Síntese histórica da Experiência Espiritual: Experiência Católica. In: GOFFI, Tullo; SECONDIN, Bruno (Org.). Problemas e perspectivas de espiritualidade. São Paulo: Edições Loyola, 1992. p. 92-93. 
percurso lógico de opiniões que tinham sido corrigidas anteriormente. No entanto, talvez por causa da conjugação de vários fatores, as pessoas não consigam superar as imprecisões que criam sobre Jesus Cristo, a saber: 0 interesse crescente na busca de informação mediática; a complexividade do conteúdo dogmático cristológico; pouca instrução de qualidade; falta de leitura ou acesso a uma literatura mais rica no desenvolvimento e na apresentação dos conceitos teológicos; etc.

De qualquer modo, a conversão pastoral também deve levar em consideração os efeitos de uma espiritualidade secularizada e subjetiva, para que, conforme Joel P. Amado indica, Jesus Cristo possa de fato se tornar o critério para se recomeçar na caminhada ${ }^{18}$. Multiplicam-se os caminhos pelos quais o pluralismo se apresenta como representante das diversas hermenêuticas, seja em nível sociocultural, seja no nível do sujeito propriamente dito. Por isso, é necessário criar esforço por reunir "o conjunto de todos os significados da realidade em uma compreensão unitária, que permita exercer a liberdade com discernimento e responsabilidade" "19. Dessa maneira, ninguém contesta a importância da centralidade de Cristo para o cristão - o que se aplica também ao discurso feito sobre a Igreja - , mas ocorre reconhecer que essa não é a única proposta essencial do Evangelho, que implica numa tomada de consciência de caráter "antropologicamente indispensável de um eixo articulador para a totalidade da vida de pessoas, grupos e povos" ${ }^{20}$.

\section{Hermenêutica pastoral da parábola do Bom Samaritano}

o que pretendemos com essas breves advertências é estabelecer, na leitura hermenêutica da parábola do bom samaritano, um cenário teológico mais equilibrado e menos unilateral, em que os princípios de cuidado com o próximo se conformem a uma eclesiologia e a uma cristologia mais adequadas. Santo Agostinho, no terceiro livro do De doctrina christiana, expõe algumas regras hermenêuticas que ele mesmo aplicava em seus discursos e sermões. A primeira regra recomenda que a análise dos textos bíblicos deva sempre levar em consideração a unidade entre

\footnotetext{
18 AMADO, Joel P. Mudança de época e conversão pastoral: uma leitura das conclusões de Aparecida. Revista Atualidade Teológica. Rio de Janeiro, ano XII, n. 30, p. 301-316, 2008. p. 306. 
Cristo e a Igreja, de tal modo que possamos enxergar, na profundidade dos elementos da revelação sagrada, o mistério da comunhão entre Deus e o seu povo que se tornou irreversível pela encarnação do Verbo divino ${ }^{21}$.

Acreditamos que os pressupostos teológicos estabelecidos pela declaração Dominus Iesus ${ }^{22}$ sejam suficientes para que não se crie nenhum risco de comprometer a validade desta proposta, já que o documento pôde esclarecer e aprofundar questões comuns à cristologia e à eclesiologia que, por sua vez, Agostinho e os Padres da Igreja jamais pensariam que pudessem afrontar.

Para Agostinho, não se tratava apenas de um recurso para a leitura alegórica dos textos do Antigo Testamento, como propunham Orígenes e Clemente de Alexandria. Na verdade, Agostinho insistiu, sobretudo no conjunto da polêmica contra os donatistas e contra os pelagianos, em formular a sua resposta a partir de textos do Novo Testamento, que pudessem ser lidos com o auxílio dessa regra hermenêutica. Por exemplo, no prólogo de João, onde literalmente se fala do Verbo Divino ${ }^{23}$, Agostinho mostra que a realidade ali apresentada é tão sublime e inacessível, por declarar o mistério da pré-existência do Verbo, que o único modo de manifestá-la é considerando o fato de Deus ter revelado esse mistério aos Apóstolos e, consequentemente, a toda Igreja. Nisso se afirma que o evangelista não pode falar apenas de Cristo, mas deve mencionar também a Igreja, por causa dessa unidade verdadeira que se realiza pelo mistério da Encarnação ${ }^{24}$. Nos Atos dos Apóstolos, a aparição de Cristo para Paulo é uma prova da comunhão entre Cristo e a Igreja, segundo Agostinho, porque, ao invés de dizer que Paulo estava perseguindo os cristãos, como se pressupõe pelos indícios históricos no próprio texto, Jesus the perguntara "Saulo, Saulo, por que me persegues?"25. Dessa vez, a Igreja perseguida "esconde" em seus membros o Cristo já ressuscitado e glorioso ${ }^{26}$.

21 AGOSTINHO DE HIPONA. A doutrina cristã: Manual de exegese e formação cristã. Trad. Ir. Nair de Assis Oliveira. São Paulo: Paulus, 2002. p. 190-191.

22 CONGREGAÇÃO PARA A DOUTRINA DA FÉ. Declaração Dominus lesus: sobre a unicidade e a universalidade salvífica de Jesus Cristo e da Igreja. 4. ed. São Paulo: Paulinas, 2001.

23 Jo $1,1$.

24 SANT'AGOSTINO. Commento al Vangelo e alla prima epistola di San Giovanni. Roma: Città Nuova, 1968. p. 11. In lo. Evang. I, 8.

25 At $9,4$.

26 SANT'AGOSTINO. Discorsi: su i tempi liturgici. XXXII/2. Roma: Città Nuova, 1969. p. $249 ; 116,7,7$. 
Por outro lado, é importante salientar que Agostinho seguia os passos de Orígenes na interpretação da parábola do samaritano, usando-a, por exemplo, em contexto sacramental:

Quase morto te abandonaram pelo caminho os ladrões, mas, já antes de jazer, foste encontrado pelo misericordioso Samaritano que também passava [por ali]; foram derramados sobre ti vinho e azeite: recebeste o sacramento do Unigênito. Foste colocado sobre o jumento dele: acreditaste no Cristo encarnado. Foste levado para a estalagem: na Igreja foste curado (tradução nossa) ${ }^{27}$.

Admitimos que, diante dos desafios pastorais e teológicos antes apresentados, podemos ampliar a interpretação da parábola do samaritano, levando em consideração a regra hermenêutica da unidade entre Cristo e a Igreja.

Nesse sentido, a ação do samaritano em favor do homem caído antecipa e ilustra que, em qualquer gesto de solidariedade para com o próximo, fazem-se presentes de uma maneira concreta Cristo e sua Igreja, em virtude daquela unidade constituída pela Encarnação do Verbo divino. Ao mesmo tempo, essa comunhão constrói para todos os homens um aconchego designado pela figura daquela hospedaria, onde o restabelecimento do homem ferido jamais pode ser completo sem que esse descubra como ele mesmo é capaz de se inserir completamente no mistério de amor entre Cristo e a Igreja.

\section{Aplicação ao plano quaresmal da campanha da fraternidade 2020}

O plano quaresmal concebido pela $\mathrm{CNBB}^{28}$ talvez seja o lugar onde estes conceitos mais se adaptem, de modo que efetivamente o processo teológico possa ser construído a partir da realidade pastoral e ao mesmo tempo possa ser efetivado num programa de atividades concretas.

$27 \quad$ "Semivivum te latrones in via dimiserunt, sed iam a transeunte et misericordi Samaritano iacens inventus es; infusum est tibi vinum et oleum, sacramentum Unigeniti percepisti; levatus es in iumentum eius, incarnatum Christum credidisti; ad stabulum perductus es, in Ecclesia curaris". SANT'AGOSTINO. Discorsi: sul N. Testamento. XXXI/2. Roma. Città Nuova, 1990. p. 382; 179A, 7.

28 CONFERÊNCIA NACIONAL DOS BISPOS DO BRASIL. CF 2020 Fraternidade e Vidadom e compromisso: "Viu, sentiu compaixão e cuidou dele". Texto-Base. Brasília: Edições CNBB, 2019. p. 6; CF 2020 n. 25. 


\subsection{Subsídios para a escuta da Palavra}

A unidade entre Cristo e a Igreja aparece na Sagrada Escritura através de duas imagens emblemáticas: a de "Corpo de Cristo" e a de "Esposa de Cristo". A Constituição Dogmática sobre a Igreja, do Concílio Vaticano II, reforça estas metáforas como representação e afirmação da Igreja como Corpo que reúne todos os remidos e Esposa fiel de Cristo: "pois, comunicando o Seu Espírito, fez misteriosamente de todos os Seus irmãos, chamados de entre todos os povos, como que o Seu Corpo"; "Cristo ama a Igreja como esposa, fazendo-se modelo do homem que ama sua mulher como o próprio corpo" 29 .

A compreensão escriturística de Igreja como Corpo de Cristo aparece em três textos neotestamentários fundamentais: 1Cor 12, 1227; Rm 12, 4-8; Jo 15, 1-17. O Corpo de Cristo em Paulo, menos que um organismo vivo e biologicamente funcionando, é mais um corpo sacramental: "já que há um único pão, nós embora muitos, somos um só corpo, visto que todos participamos desse único pão" ${ }^{30}$. Sendo assim, pelo batismo em Cristo, nos tornamos membros de seu povo, Povo de Deus, e esta união pneumática entre o fiel e o seu Senhor ocorre na graça do Espírito Santo que nos foi concedido. Ao sermos batizados, é no Cristo que o fomos; ao comungarmos, é o Cristo que comungamos; e assim tornamo-nos membros de seu Corpo como comunidade de fé, como raça eleita, povo Santo. E é esta pertença a Cristo que permite a nossa união fraterna: "nós somos muito e formamos um só corpo em Cristo, sendo membros uns dos outros" ${ }^{31}$. A unidade eclesial nasce da unidade do Filho redentor com as filhas e filhos redimidos; da Cabeça que é Cristo com o seu Corpo que é a Igreja de Cristo; num vínculo esponsal, unidos na graça do Espírito, Cristo e a Igreja formam um único Corpo.

Contudo, o texto que melhor expõe a unidade entre Jesus Cristo e a Igreja, como Corpo de Cristo é a parábola da videira: "Eu sou a videira e vós os ramos. Aquele que permanece em mim e eu nele produz muito fruto; porque sem mim nada podeis fazer" ${ }^{\prime 3}$. A unidade

29 CONCÍLIO VATICANO II, 1962-1965, Vaticano. Constituição Dogmática Lumen Gentium. In: VIER, Frederico (Coord.). Compêndio do Vaticano Il: constituições, decretos, declarações. 23. ed. Rio de Janeiro: Vozes, 1994. p. 37-117. p. cit. 41; LG 7.

301 Cor 10,17 .

$31 \mathrm{Rm} 12,5$.

32 Jo 15,5 . 
entre Cristo (videira) e os fiéis (ramos), não é somente uma união espiritual e um vínculo afetivo, mas sim é uma unidade de vida e de geração de vida. O que permanece ligado ao Senhor é aquele que produz fruto (vida), aquele que, a exemplo do Mestre, não guarda para si os dons que recebeu, mas os coloca a serviço para que todo o corpo eclesial cresça. A única opção para a Igreja é permanecer unida a Cristo, pois ela é a Igreja de Cristo, o Povo de Deus, e esta permanência é frutífera, pois Cristo deseja que a comunidade de fé cresça e floresça verdejante.

A comunhão dos membros do Corpo com a Cabeça representa não um vínculo de dominação, mas sim um mistério do amor entre Cristo (cabeça) e a Igreja (membros), enquanto comunhão que constitui unidade na diversidade. A Igreja como noiva ou esposa expressa esse vínculo permanente com Cristo ${ }^{33}$. "Por isso um homem deixa seu pai e sua mãe, se une à sua mulher, e eles se tornam uma só carne" ${ }^{34}$, neste relato da Criação é possível fazer uma analogia do amor esponsal entre Cristo e a Igreja, com o amor entre os esposos projetado pelo Criador numa comunhão de vida, de realidades, de graça e de missão.

Vários são os relatos escriturísticos que fazem uso das núpcias como forma de ensinar ou admoestar sobre algo ${ }^{35}$. No Apocalipse de João, "vi também descer do céu, de junto de Deus, a Cidade santa, uma Jerusalém nova, pronta com uma esposa que se enfeitou para seu marido" a perspectiva esponsal aparece claramente, pois é a Igreja, como a Jerusalém celeste, que vem ao encontro do Cristo, o Cordeiro imolado. A unidade entre Cristo e a Igreja na perspectiva esponsal preserva uma característica importante de ambos: a pessoalidade. Cada uma das "pessoas" conserva a sua diferença, enquanto a ação do Cristo a torna pura, santa e imaculada. Portanto "como Cristo é a cabeça da Igreja e o salvador do Corpo"36 a Esposa é acolhida pelo seu Senhor e Redentor, para apresentá-la pura e sem mancha; o que possibilita esta nova ornamentação é o amor de Cristo pela Igreja ${ }^{37}$.

33 KASPER, Walter. A Igreja Católica: essência, realidade, missão. São Leopoldo: Unisinos, 2012. p.181. 


\subsection{A atenção ao próximo}

O lema da Campanha da Fraternidade 2020 aponta para duas realidades da vida. Em primeiro lugar, devemos receber gratuitamente de Deus, como um dom, as suas dádivas. Em segundo lugar, temos um compromisso, não apenas em cultivar a própria vida, mas também cuidar do próximo cujas feridas precisam de cuidado, sobretudo dos que vivem nas periferias existenciais, pois "não se pode viver a vida passando ao largo das dores dos irmãos e irmãs" 38 .

A pergunta do doutor da lei ${ }^{39}$ continua ecoando e exigindo, sobretudo dos cristãos, uma resposta definitiva: quem é verdadeiramente o nosso próximo? Sem mais divagações, é "todo aquele que sofre diante de nós" ${ }^{40}$. Dispensar atenção ao próximo que sofre é a resposta de uma fé madura, que não escolhe quem amar, mas sabe que deve amar sem distinção. É importante olhar para o próximo que sofre sem levar em consideração quem ele é, o que ele faz, de onde ele vem, para reconhecer o fato fato dele ser alguém, criado à imagem de Deus, por isso, ele se torna digno de cuidados.

A proposta do plano quaresmal nos convida a refletir sobre como tem sido o nosso olhar? De indiferença como aquele do sacerdote e do levita ou um olhar que verdadeiramente enxerga o próximo caído e necessitado de cuidados? "Um olhar que vê e passa adiante representa toda indiferença e desprezo pela vida do outro" $"$.

Atualmente em nosso país são muitos o que se encontram caídos à beira do caminho e é um imperativo que nosso olhar não seja de indiferença para que se cruze com o caminho do próximo que corre o risco de ser abortado, que passa fome e vive na extrema pobreza, dos migrantes, dos refugiados e vítimas do tráfico, dos que são abusados sexualmente, das vítimas do trabalho infantil, das mulheres maltratadas, dos que não têm moradia, daqueles com risco eminente de cometer suicídio, dos indígenas etc. Qual seria o olhar do samaritano diante destes caídos pelo caminho? Como olhar para eles demonstrando aquela comunhão que nasce da unidade entre Cristo e a Igreja? E o nosso olhar, como tem sido? A vida está sendo ameaçada em todos em sentidos, por isso,

\footnotetext{
38 CNBB, 2019, p. 3; CF 2020 n. 6.

39 LC 10,29.

40 CNBB, 2019, p. 5; CF 2020 n. 18.

41 CNBB, 2019, p. 11; CF 2020 n. 38.
} 
o que temos feito para reverter este quadro? "Essas ameaças à vida têm nome: aborto, eutanásia, suicídio assistido, eugenia, tráfego de drogas, de pessoas e de órgãos entre outros" ${ }^{\prime 2}$.

A vida tornou-se algo banal, descartável e, para muitas pessoas, simplesmente não faz mais sentido estar vivo, pois deixou de encarar a vida como Dom de Deus e sem o menor compromisso consigo e muito menos com o próximo. O mundo atual avalia o ser humano pela sua capacidade de produção e consumo, ou seja, uma verdadeira mercantilização da vida ${ }^{43}$, onde certamente impera a lógica do cada um por si. O valor da vida do próximo fica cada vez mais distante de nossos olhares.

O olhar da indiferença, do passar adiante, tem deixado muitos caídos à beira do caminho. A falta de atenção e cuidado com as feridas do próximo, unidas ao egoísmo, têm ceifado muitas vidas e certamente seremos cobrados. Somente assumindo um olhar verdadeiramente solidário, capaz de cuidar, como modo de ser no mundo, é que conseguiremos ir além e ultrapassar a indiferença e egoísmo ${ }^{44}$.

\subsection{0 mistério sofrimento}

O sofrimento é uma realidade sempre presente na existência humana. No relato da Criação o autor bíblico apresenta que a condenação dos nossos primeiros pais, ao serem expulsos do paraíso, foi o sofrimento: "À mulher ele disse: multiplicarei as dores de tuas gravidezes, na dor darás à luz filhos" ${ }^{45}$; "Ao homem, ele disse: Com sofrimentos dele [do solo] te nutrirás todos os dias de tua vida" ${ }^{46}$. Aqui é possível compreender a afirmação de João Paulo II: "O homem sofre por causa do mal, que é uma certa falta, limitação ou distorção do bem. Poder-se-ia dizer que o homem sofre por causa de um bem do qual não participa, do qual é, num certo sentido, excluído, ou do qual ele próprio se privou"47. $\mathrm{O}$ cristão proclama sempre a existência de um bem como fundamental; a bondade

\footnotetext{
CNBB, 2019, p. 18; CF 2020 n. 58.

CNBB, 2019, p. 19; CF 2020 n. 62.

CNBB, 2019, p. 27; CF 2020 n. 91.

45 Gn 3,16.

46 Gn $3,17$.

47 JOÃO PAULO II. Carta Apostólica Salvifici doloris. Vaticano, 1984; SD 7. Disponível em: < http://w2.vatican.va/content/john-paul-ii/pt/apost_letters/1984/documents/hf_jp-ii_apl_11021984_salvifici-doloris.html>. Acesso em: 29 out. 2019.
} 
do Criador é manifestação deste bem e também este Deus proclama um bem nas criaturas.

Além do sofrimento do corpo, há uma realidade mais profunda de sofrimento: "o olhar que vê e passa adiante representa toda indiferença e desprezo pela vida do outro"48. A ausência de compaixão ao contemplar o rosto de tantos irmãos e irmãs caídos pelo caminho mostra ausência de compreensão da existência do bem, "Deus viu tudo o que tinha feito: e era muito bom" $"$.

A partir da parábola do bom samaritano é possível dizer que o sofrimento humano se faz presente em nossa realidade sob tantos aspectos, João Paulo II reitera que isto se faz presente para desencadear no homem o amor, ou seja, esse dom desinteressado do próprio eu em favor do próximo, da pessoa que sofre. O mundo do sofrimento humano almeja sem cessar uma outra realidade: o amor humano. $\mathrm{O}$ amor desinteressado que vem do coração e transparece nas ações da pessoa que sofre ${ }^{50}$.

Em Jesus Cristo, Filho unigênito de Deus, Encarnado em nosso meio para nos mostrar o projeto de Amor do Pai, descobrimos uma nova forma de olhar, sentir, compreender a realidade do sofrimento humano. Pois como afirma o profeta Isaías "eram nossos sofrimentos que ele levava sobre si, nossas dores que ele carregava" 51 e o diálogo do bom ladrão com Jesus no relato da crucificação ${ }^{52}$ nos apresenta a profissão de fé do ladrão crucificado na salvação do Cristo como perspectiva de um sofrimento em vista de um bem fundamental, isto é, a salvação.

No Corpo de Cristo sofredor e morto na cruz pendeu a salvação de todos. Pois o próprio Senhor escreveu este Evangelho de redenção com o seu sofrimento assumido por amor, a fim de que o homem não pereça, mas tenha a vida eterna ${ }^{53}$. Todos participamos do mistério da salvação que o Senhor nos ofereceu ao pender no madeiro da cruz, um mal aparente que se manifesta em bem fundamental. Deus não permitiu a crucificação do seu Filho pelo gosto do mal representado no sofrimento, mas para que, por este sofrimento, todos alcançássemos o mesmo e enorme tesouro

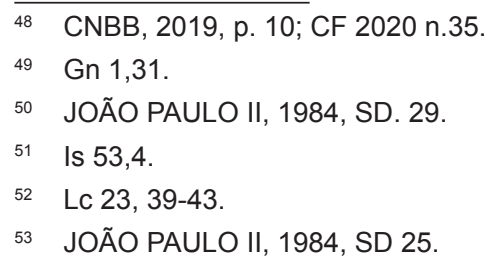


que João Crisóstomo tinha encontrado ao exclamar que se alegrava por ter achado riquezas extraordinárias, referindo-se ao que tinha acontecido com Cristo, cordeiro de Deus, pois os judeus tinham matado um cordeiro para que nós pudéssemos receber o fruto do sacrifício ${ }^{54}$. O tesouro que João Crisóstomo encontrou foi um bem fundamental e não somente para si, mas para todos.

Paulo ao apresentar a metáfora da Igreja com Corpo de Cristo $^{55}$ aborda uma outra perspectiva do sofrimento: "se um membro sofre, todos os membros compartilham o seu sofrimento" ${ }^{56}$. Se o sofrimento de Cristo gerou vida e salvação para toda Criação, agora Paulo aborda a perspectiva fraterna do sofrimento, não numa proposta de compartilhamento do mal, mas sim na direção da fraternidade como fundamento para o bem. Ou seja, o Cristo no seu Amor por nós ofereceu a vida como doação gratuita, convidando a todos que aceitem a Boa Nova: "dei-vos o exemplo para que, como eu vos fiz, também vós o façais" ${ }^{57}$. A Comunidade dos fiéis, seguindo o modelo de seu Mestre e Senhor, vive e professa os seus ensinamentos, colocando em prática o que proporciona a consolidação e fortalecimento dos vínculos que unem a Igreja neste único Corpo do Senhor. Sendo assim, Paulo exorta a comunidade de Roma e a nós: "Alegrai-vos com os que se alegram, chorai com os que choram" 58 .

\subsection{Gestos efetivos e permanentes}

Se nos perguntássemos até quando devemos prestar a atenção cuidadosa ao próximo, poderíamos dizer que o limite é até que esse se levante e saia curado daquela hospedaria em que o samaritano o deixou. Em termos práticos isso sugere algumas iniciativas que jamais podem permanecer limitadas no espaço de tempo. Por isso, os quarenta dias da quaresma são apenas uma provocação para dinamizar atitudes que se tornem perenes. Em nenhum momento se cobrou ao homem caído que se levantasse depressa demais ou que ficasse curado o quanto antes. Isto impregna de significado as palavras de Cristo, mostrando-nos que a vida é a própria medida e a dignidade humana é a condição em que

\footnotetext{
54 JEAN CHRYSOSTOME. Huit catéchèses baptismales inédites. Trad. Antoine Wenger, Paris: Sources Chrétiennes 50, 2005. 174, 177.

$58 \mathrm{Rm} 12,15$.
} 
se espera encontrar o próximo. O próximo a ser cuidado tem nome, por isso não pode ser esquecido. No momento em que nós o encontrarmos, só podemos ir embora quando esse já estiver numa condição humana de segurança e paz.

\section{Considerações conclusivas}

Referindo-se ao Evangelho de Lucas, embora que estivesse comentando outro capítulo, Waldecir Gonzaga afirma que a misericórdia é algo que se constata pela ação e não por uma expressão literária ${ }^{59}$. O samaritano, o próximo e a hospedaria compõem um cenário autêntico da vida pastoral no Brasil e no mundo, conjugando questões práticas que necessitam de permanente atenção. A voz dos senhores Bispos comunica a devida oportunidade para que nos aprofundemos cada dia mais sobre este assunto.

\section{Referências bibliográficas}

AGOSTINHO DE HIPONA. A doutrina cristã: Manual de exegese e formação cristã. Trad. Ir. Nair de Assis Oliveira. São Paulo: Paulus, 2002. AMADO, Joel P. Mudança de época e conversão pastoral: uma leitura das conclusões de Aparecida. Revista Atualidade Teológica. Rio de Janeiro, ano XII, n. 30, p. 301-316, 2008.

AUMANN, Jordan. Síntese histórica da Experiência Espiritual: Experiência Católica. In: GOFFI, Tullo; SECONDIN, Bruno (Org.). Problemas e perspectivas de espiritualidade. São Paulo: Loyola, 1992. p. 92-93.

BENTO XVI. Jesus de Nazaré: Do batismo no Jordão à Transfiguração. Trad. José J. F. de Farias. São Paulo: Planeta do Brasil, 2007.

BÍBLIA de Jerusalém. 5. ed. São Paulo: Paulus, 2008.

CONCÍLIO VATICANO II, 1962-1965, Vaticano. Constituição Dogmática Lumen Gentium. In: VIER, Frederico (Coord.). Compêndio do Vaticano II: constituições, decretos, declarações. 23. ed. Rio de Janeiro: Vozes, 1994. p. 37-117.

59 GONZAGA, Waldecir. Um Cristo Compassivo e misericordioso (Lc 15,11-32). In: FERNANDES, Leonardo A. (Org.) Traços da Misericórdia de Deus segundo Lucas. Rio de Janeiro: Editora PUC-Rio; Santo André: Editora Academia Cristã, 2016. p. 90-112; p. 94. 
CONFERÊNCIA GERAL DO EPISCOPADO LATINO-AMERICANO E DO CARIBE, V, 2007, Aparecida. Documento de Aparecida: texto conclusivo. 7. ed. Brasília: CNBB, 2008.

CONFERÊNCIANACIONAL DOS BISPOS DO BRASIL. CF 2020 Fraternidade e Vida - dom e compromisso: "Viu, sentiu compaixão e cuidou dele”. Texto Base. Brasília: Edições CNBB, 2019. p. 6; CF 2020 n. 25.

CONGREGAÇÃO PARAA DOUTRINA DA FÉ. Declaração Dominus Iesus: sobre a unicidade e a universalidade salvífica de Jesus Cristo e da Igreja. 4. ed. São Paulo: Paulinas, 2001.

FRANCISCO. Exortação Apostólica Evangelii Gaudium. Brasília: Edições CNBB, 2013. p. 63; EG 102.

GONZAGA, Waldecir. Um Cristo Compassivo e misericordioso (Lc 15, 11-32). In: FERNANDES, Leonardo A. (Org.) Traços da Misericórdia de Deus segundo Lucas. Rio de Janeiro: Editora PUC-Rio; Santo André: Academia Cristã, 2016. p. 90-112.

JEAN CHRYSOSTOME. Huit catéchèses baptismales inédites. Trad. Antoine Wenger, Paris: Sources Chrétiennes 50, 2005.

JOÃO PAULO II. Carta Apostólica Salvifici doloris. Vaticano, 1984. Disponível em: $<$ http://w2.vatican.va/content/john-paul-ii/pt/apost_letters/1984/documents/hf_jp-ii_apl_11021984_salvifici-doloris.html >. Acesso em: 29 out. 2019.

KASPER, Walter. A Igreja Católica: essência, realidade, missão. São Leopoldo-RS: Editora Unisinos, 2012.

LEVINE, Amy J.; WINTERINGTON, Ben. The Gospel of Luke. Cambridge: Cambridge University Press, 2018.

MENESES, Ramiro D. B. O vulnerável segundo a parábola do Bom Samaritano. Revista Cultura Teológica, São Paulo, v. 14, n. 56, p. 9-35, jul/set 2006.

MIRANDA, Mário de F. Inculturação da fé: uma abordagem teológica. São Paulo: Loyola, 2001.

ORIGEN. Homilies on Luke: Fragments on Luke. Trad. Joseph T. Lienhard. New York: The Catholic University of America Press, 1996.

RATZINGER, Joseph. Convocados en el camino de la fe: La iglesia como comunión. Trad. José R. M. Fernandez. Madrid: Cristiandad, 2004. 
SANT'AGOSTINO. Commento al Vangelo e alla prima epistola di San Giovanni. Roma: Città Nuova, 1968.

SANT'AGOSTINO. Discorsi: su i tempi liturgici. XXXII/2. Roma: Città Nuova, 1969.

SANT'AGOSTINO. Discorsi: sul N. Testamento. XXXI/2. Roma. Città Nuova, 1990.

SILVA, Ezequiel M. Una teología samaritana: el estilo teológico de Jon Sobrino. Revista Teología, Buenos Aires, T. XLVII, n. 104, p. 81-109, abril 2011.

SILVEIRA FILHO, Alencar. O processo de diversificação denominacional do protestantismo brasileiro. Revista Unitas, Vitória, v. 5, n. 1, p. 187-202, 2017.

SUESS, Paulo. Perspectivas pastorais em vista do terceiro milênio. Revista de Cultura Teológica, São Paulo, n. 17, p. 9-27, out/dez 1996. 